\title{
Environmental Risk Assessment of Heavy Metals of Road Runoff in Ehimiri Housing Estate Umuahia, Abia State, Nigeria
}

\author{
${ }^{1}$ Lazarus O.Ikwa . ${ }^{2}$ Doris Ndubueze , ${ }^{3}$ Uchechi Ogidi U, ${ }^{4}$ Ifunaya Omenka , Iloghalu,M \\ ${ }^{I}$ Department of Forestry and Environmental Management, Michael Okpara University of Agriculture, Umudike \\ Umuahia Abia State, Nigeria. ${ }^{2}$ Department of Physics Michael Okpara University of Agriculture, Umudike \\ Umuahia Abia State, Nigeria \\ 3. Department of Soil Science and meteorology Michael Okpara University of Agriculture, Umudike \\ Umuahia Abia State, Nigeria \\ ${ }^{4}$ Department of Biochemistry Michael Okpara University of Agriculture, Umudike Umuahia Abia State, Nigeria \\ ${ }^{5}$ Department of Environmental Manegement Toxicology Michael Okpara University of Agriculture, Umudike \\ Umuahia Abia State, Nigeria
}

\begin{abstract}
The study focused on the environmental risk evaluation of heavy metals in road runoff as non-point source in Ehimiri housing Estate Umuahia. Absorption Atomic Spectrophotometer was used for the analysis. The major streets selected include Sam Onyeozari street (ERSP1), Ukpai A.Ukpai street (ERSP2), Dick Uduma stree (ERSP3), Justice Atuma Street (ERSP4), Ibe Nwachukwu (ERSP5), Mazi Uwakaeme (ERSP6), and Nwogu street (ERSP7) respectively. A total of twenty one runoff samples, three each from the seven selected roads were collected across three months (May-August, 2014), and analyzed using standard methods. Results shown that heavy metal concentrations originating from the non-point source (NPS) in the selected routes were in the following ranges: $\mathrm{Cd}(0.01-0.02 \mu \mathrm{g} / \mathrm{l}-1), \mathrm{Cu}(10.00-45.00 \mu \mathrm{g} / \mathrm{l}-1), \mathrm{Cr}(0.05-4.01 \mu \mathrm{g} / \mathrm{l}-1), \mathrm{Zn}(5.00-50.00 \mu \mathrm{g} / \mathrm{l}-$ $1)$, and $\mathrm{Pb}(1.64-29.01 \mu \mathrm{g} / \mathrm{l}-1)$, which further explained that concentrations were higher in the months of April and May in Aba road and reduced in other routes. An increased in heavy metals were observed during the month of July than the month of May. Statistically, mean variations were observed among heavy metals from road runoff that ranged between: $\mathrm{Cd} 0.07 \mu \mathrm{g} / \mathrm{l}-1, \mathrm{Cr} 3.10 \mu \mathrm{g} / \mathrm{l}-1, \mathrm{Cu} 22.70 \mu \mathrm{g} / \mathrm{l}-1, \mathrm{~Pb} 36.70 \mu \mathrm{g} / \mathrm{l}-1$ and $\mathrm{Zn} 51.40 \mu \mathrm{g} / \mathrm{l}-$ 1in order of $\mathrm{Zn}>\mathrm{Pb}>\mathrm{Cu}>\mathrm{Cr}>\mathrm{Cd}$ respectively. The results also indicated that $\mathrm{Cd}, \mathrm{Cu}, \mathrm{Cr}, \mathrm{Zn}$ and $\mathrm{Pb}$ concentrations in road runoff sampled were above the NESREA and WHO standards for potable water during the month of April being first flush, May being the after first flush and July that proceeds August break that affects man and his environment.
\end{abstract}

Keywords: Atomic Absorption Spectrophotometer, Environmental Risk ,Heavy Metals, Road runoff, Umuahia.

\section{INTRODUCTION}

Rainwater runoff from urbanized areas has in the recent years received increasing attention from the public and scientific community, because it is perceived to induce deleterious effects on the aquatic biota and valuable ecosystem component (Ubuoh, 2013 Chèvre, et al, 2007) Indeed, several studies have shown that a wide variety of pollutants are present in rainwater runoff, mainly resulting from the wash-off of the surfaces (Burton and Pitt 2002). For example, heavy metals emitted from traffics are commonly detected in rainwater runoff, but also pesticides (Revitt et al; 2002; Ukabiala et al, 2010; Gajghated and Hassan, 1999; Polkowska et al, 2001; Preciado, and .Li, 2006; Elbgermi et al; 2013) or biocides used in building material (Burkhardt et al. 2005). Most of the heavy metals when released become bound to the road surfaces, dust or other particulates. During rainfall, the bound metals are either dissolved or swept off the road by runoff. Indeed, several studies have shown that a wide variety of pollutants are present in rainwater runoff, mainly resulting from the wash-off of the surfaces (Burton and Pitt, 2002). In separate sewer system, this pollution often ends in rivers without any treatment and consequently impacts on aquatic life are expected. It is therefore crucial to assess the risk of rainwater runoff pollution. According to Sansalone et al (1196), Ukabiala et al (2010), rainfall runoff from urban roads often contains significant quantities of dissolved metal elements (DEM), particulate -bound metal elements (PME), and suspended, colloidal and volatile fractions of particulates. These metals carried inroad runoff and percolate into the soils within the surrounding environment or may end up in various water sources (Duzgoren-Aydin et al, 2006; Florea, 2006). The 
Lazarus O.Ikwa et al. "Environmental Risk Assessment of Heavy Metals of Road Runoff in Ehimiri Housing Estate Umuahia, Abia State, Nigeria"

continuous increase in heavy metal contamination of estuaries and coastal waters is a cause for concern as these metals have the ability to bio-accumulate in tissues of various biotas and may also affect the distribution and density of benthic organisms (Griggs et al, 1997) Environmental risk assessment is commonly done by comparing measured environmental concentrations with water quality criteria set to protect the aquatic life for a long period of time (European Commission 2003). However, these long-term criteria are not suitable to estimate the effects of the highly dynamic pollution resulting from wet-weather discharge. Indeed, the contaminants reach surface waters directly through surface runoff during rain events and occur at maximum concentrations just after reaching the water body. This exposure pattern results in time-varying and repeated contamination of the aquatic system. Very little is known about the effects of hort but high peaks of exposure. Standard laboratory toxicity tests usually used to assess the effects of pollutants utilize continuous exposure scenarios and typically do not investigate the toxicity of short-term pulsed or intermittent exposures to aquatic organisms. In fact, the necessity in assessing the effects of such high concentrations events have been discussed by several authors (Brent and Herricks 1999; Reinert et al. 2002; Diamond et al. 2006).the study therefore seeks to assess the impact of run off on the quality of the Ehimiri river because of its usefulness to the people of the area who use it for domestic, industrial and agricultural purposes.

\section{STUDY LOCATION AND DESCRIPTION}

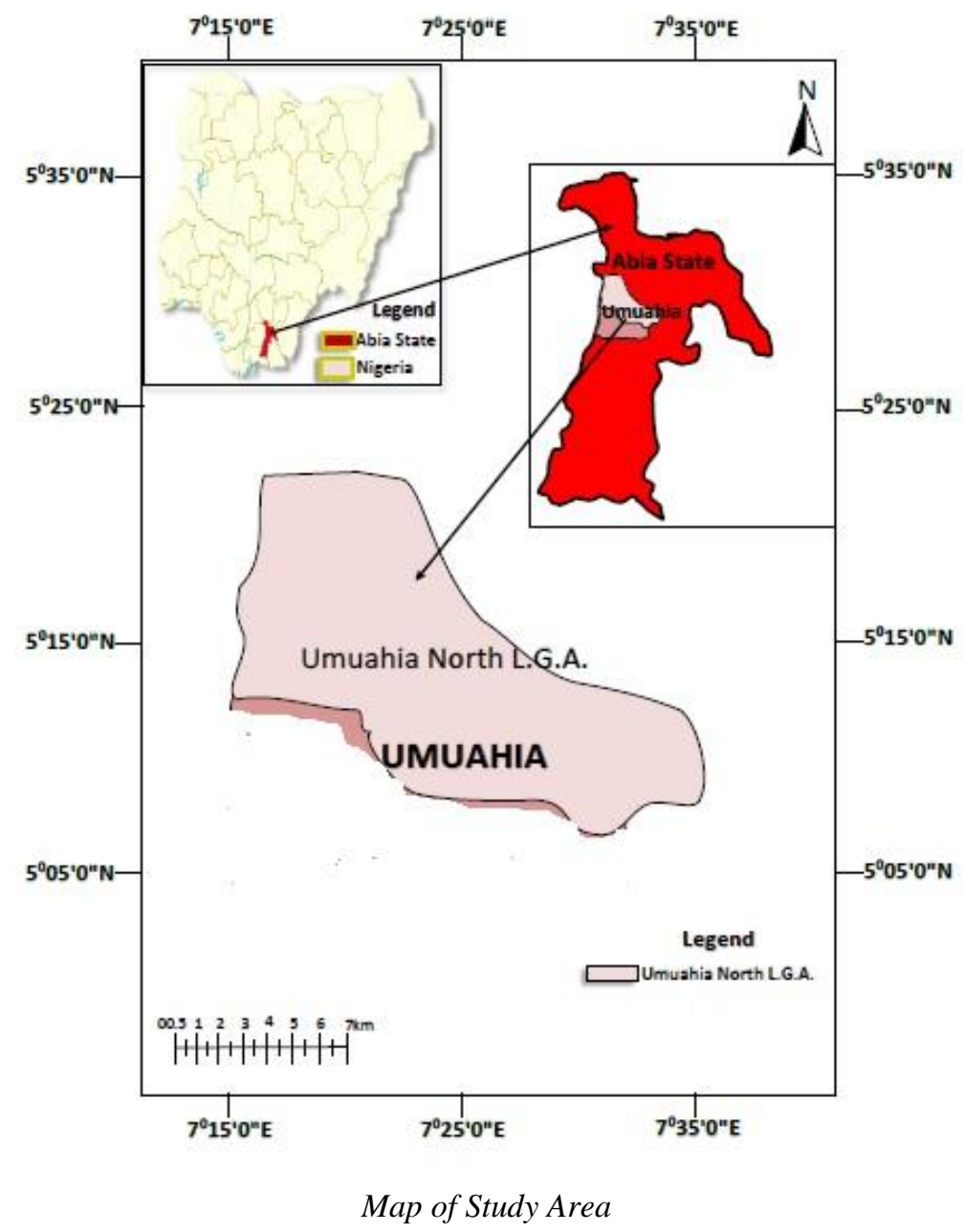

The study was conducted at Ehimiri housing Esate,Umuahia North LGA of ,Abia State Nigeria. Umuahia North Covers an area of approximately $5834 \mathrm{~km}$ and lies between latitude $4^{0} 40^{1}$ and $6^{0} 14^{1} \mathrm{~N}$ and longitude $7^{0} 10^{1}$ and $8^{0} \mathrm{E}$ (WRM, 2003).it is bounded in the north uzoakoli LGA,; to the West by obowo; to the east and south by Ikwuano L.G.A. The area has two distinct seasons in a year, rainy season and dry season. The rainy season covers a period of seven months from April to October, while the dry season lasts for five months from November to March each year. The mean annual climate data in Abia State are as follows: maximum and minimum temperature of $32^{\circ} \mathrm{c}$ and $25^{\circ} \mathrm{c}$ respectively. Rainfall of $2400 \mathrm{~mm}$, and a range of relative humidity of $80-90 \%$ (Oyenuga 1967; 
Lazarus O.Ikwa et al. "Environmental Risk Assessment of Heavy Metals of Road Runoff in Ehimiri Housing Estate Umuahia, Abia State, Nigeria"

Aregheore, 2005; NRCRI, 2013) Umuahia North is is about $122 \mathrm{~m}$ above sea level. The state has three major agro ecological zone, namely fresh water swamp forest, rainforest and derived savannah (Keay, 1959, white,1983, Ofamata, 2001) The vegetation in Umuahia North is typical of rain forest. The city is located at the centre of an extensive agricultural region which covers most of the central part of Abia State. It is also strategically located along a well established north-south trading and transportation route. Ehimiri housing Estate is a planned unit of settlement in Umuahia metropolis like other housing estates in Abia state. The residents are mostly civil servants pety traders and farmers. The nucleated type settlement made of well arrange housing form the housing pattern of the area.

\section{Geology}

The Geology of umuahia includes the Pre-Cambrian Oban Massif, Cretaceous sediments of the Calabar flank and the recent Niger Delta sedimentary basin. The basin is about 43 kilometers $(27 \mathrm{mi})$ wide and 62 kilometers $(39 \mathrm{mi})$ long, with an area of 1,514 square kilometers (585 sq mi) At one time it was entirely covered by tropical rainforest. The basin has streams with a total length of 516 kilometers $(321 \mathrm{mi})$. This is a small number given the size of the basin. Drainage is poor, so the basin is subject to flooding, gully erosion and landslides.

\section{Climate}

Under Koppen's climate classification umuahia features a tropical climate with a lengthy wet season spanning ten months and a short dry season covering the remaining two months. The harmattan, which generally significantly influences weather in West Africa, is noticeably less pronounced in the city. Temperatures are relatively constant throughout the course of the year. There is also little variance between daytime and nighttime temperatures as temperatures at night are generally only a few degrees lower than the high temperature, which is typically attained during the daytime Average temperatures range from $24^{\circ} \mathrm{C}\left(75^{\circ} \mathrm{F}\right)$ in August to $30^{\circ} \mathrm{C}\left(86^{\circ} \mathrm{F}\right)$ in February. umuahia averages just under $3,000 \mathrm{~mm}$ of precipitation annually. Relative humidity is high, between $80 \%$ and $100 \%$.

\section{Soil Type}

The soil at the study site had sandy clay-loam texture, acidic and of medium fertility with a water table > 40M. Its pre-cambrian oban massif cretaceous sediments origin makes the soils unique (Ofomata, 1975; NRCRI, 2013)

\section{Selected Roads and Runoff Sample Collection}

Road runoff samples were collected between the months of July- September, 2014 in order to investigate the effect of months and intensity of rainfall on heavy metal concentrations in road runoff (RR). This was done on the seven selected routes in Ehimri Housing Estae. The sample points selected were two meters from the main drainage system where the pool of water was found. The sample points selected were designated Ehimiri Road Runoff Sample Points (ERSP1- 7) to include Sam Onyeozari street (ERSP1), Ukpai A.Ukpai street (ERSP2), Dick Uduma street Ukpo street(ERSP3), Justice Atuma Street (ERSP4), Ibe Nwachukwu(ERSP 5), Mazi Uwakaeme street (ERSP6), and Sir Nwogu street (ERSP7).These routes were selected based on the volume of run off in the area.

\section{Sample Preparation and Analysis}

Prior to sample collection, the two - liter plastic cans were properly cleansed and rinsed using distilled water. The collections were carried out by carefully dipping the sample cans into the pool of runoff water during rain events. Thereafter, the cans were tightly covered in order to avoid contamination. They were stored in a refrigerator at $4 \mathrm{o} \mathrm{C}$ prior to analysis. The laboratory analysis of the runoff samples were done using Scientific 200 Model Atomic absorption Spectrophotometer (AAS) to determine the concentration of the selected heavy metals like lead, cadmium, copper, chromium, zinc, and manganese in the runoff samples. The road runoff water samples were digested using concentrated nitric acid HNO3 and concentration of Lead $(\mathrm{Pb})$, Zinc ( $\mathrm{Zn})$, Cadmium $(\mathrm{Cd})$, copper $(\mathrm{Cu})$ and Chromium (Cr),Iron(Fe),Nickel(Ni), measured on a M-scientific 200 model atomic absorption spectrophotometer (AAS) ( Agirtas, and Kilicel, 1999; Williams et al, 2007; Essien and Nsikak,2006; Adekoya and Williams 2006) at New concept Laboratory, Owerri, Imo State, Nigeria . The essence of the digestion before analysis was to reduce organic matter interference and convert metal to a form that can be analyzed by AAS (Ukabiala, 2010). Inference of the overall heavy metal 
Lazarus O.Ikwa et al. "Environmental Risk Assessment of Heavy Metals of Road Runoff in Ehimiri Housing Estate Umuahia, Abia State, Nigeria"

concentrations in road runoff was drawn by using Mean, standard Deviation and Coefficient of Variation. The results of the analyses were compared to Federal Ministry of Environment, National Environmental Safety and Regulation Agency (NESREA) and World Health Organization (WHO) Standards for potable water as it affect man and his environment (WHO, NESREA, FMENV, 2006).

\section{Determination of Iron}

Iron was determined by EPA phenantroline method 315B using HR83200 multiparameter bench photometer at wavelength of $525 \mathrm{~nm} .10 \mathrm{ml}$ of the sample was poured into two separate sample cell bottles. One was used as blank to zero the photometer and one sachet of HR93721-0 Reagent was added to the second sample cell bottle and was swirled to mix properly. It was then inserted into the cell compartment and timed for $30 \mathrm{mins}$. At the end of the countdown, the read button was pressed to display the result in $\mathrm{mg} / \mathrm{l}$ of Iron.

\section{Determination of Nickel}

Nickel was determined through the adoption of the standard methods for the examination of waste water otherwise known as Periodate Method. This was done using the HR832000 multi-parameter bench photometer at a wavelength of $525 \mathrm{~nm} .10 \mathrm{ml}$ of the un-reacted sample was pilled in the $10 \mathrm{ml}$ curvette up to the mark. This is the blank and was placed into the photometer holder or compartment and closed the lid. The zero key was pressed to display the " $0-0$ ", and now ready for measurement. It was removed and H1 93709A-0 citrate reagent was added first, mixed gently for 2 mins and added H1 93709B-0 sodium periodate reagent was then added next. This was shaken again for 2 minutes. It was then reinserted again into the instrument and the timer was pressed to display the countdown for 90seconds. After which the Read button/key was pressed to display the result in $\mathrm{mg} / \mathrm{l}$ of nickel

\section{Determination of Copper}

Copper was determined by Bicinchonate method using H1 83200 multi-parameter Bench photo-meter at a wavelength of $575 \mathrm{~nm} .10 \mathrm{ml}$ of the sample was poured into two separate sample cell bottles. One was used as blank to zero the photo-meter and one sachet of H1 93702-0 Bicinchomnate Reagent was added to the second sample cell bottle and was swirled to mix properly. It was then inserted into the cell compartment and timed for 4seconds. At the end of the countdown, the READ button was pressed to display the result in $\mathrm{mg} / \mathrm{l}$ of copper.

\section{Determination of Zinc}

Zinc was determined by Zinc method by the adoption of the standard methods for the examination of water and waste water at a wavelength of $575 \mathrm{~nm}$. This was done using the $\mathrm{H} 183200$ multi-parameter bench photo-meter. Two reagent were used H1 93731A and H1 93731B. 20mls of the sample was measured in a graduated mixing cylinder. H1 93731A zinc reagent powder was added and the cylinder was inverted several times to mix until completely dissolved. The reaction between zinc and other reagents causes an orange to a dark violet tint in the sample. The $10 \mathrm{ml}$ curvette was Pilled with the sample and inserted into the cell compartment of the instrument. It was then zeroed and ready for measurement. The curvette was removed and 0.5ml of H1 93731B (Cyclohexanone) was added and mixed for 15seconds and re-inserted into the cell compartment of the instrument. The timer button was pressed and count-down of 210seconds after which the READ button was pressed and the result displayed in $\mathrm{mg} / \mathrm{l}$ of Zinc.

\section{Determination of Cadmium}

Cadmium was determined by Dithizone method using $\mathrm{HACH}$ DR/2010 portable date logging spectrophotometer at a wavelength of $515 \mathrm{~nm}$ and program number of 60 . A $250 \mathrm{ml}$ graduated cylinder was filled with $250 \mathrm{ml}$ of the water sample and the sample was poured into a separate funnel. One buffer powder pillow, citrate type for heavy metals was added and stopper inserted and shakes to dissolve. The $30 \mathrm{ml}$ of chloroform was added to a $50 \mathrm{ml}$ mixing graduated cylinder and one content of Dithiver metal reagent powder pillow was also added and stopped. $20 \mathrm{ml}$ of $50 \% \mathrm{HaOH}$ solution was added with $0.1 \mathrm{~g}$ scoop of potassium cyanide of the funnel and shake vigorously for 15 seonds. The stopper was removed and allowed to stand for one minute. $30 \mathrm{ml}$ of Dithiver solution was added to the $500 \mathrm{ml}$ separating funnel and stopped, invert and open to vent. The stopcock was closed and the funnel shaken again for once or twice to vent again for 60seconds. The funnel was allowed to stand undisturbed for about one minute. A cotton plug was inserted into the delivery tube of the funnel and slowly drains the bottom (chloroform) layer into a dry $25 \mathrm{ml}$ sample cell. $25 \mathrm{ml}$ sample cell was filled with chloroform (blank). 
Lazarus O.Ikwa et al. "Environmental Risk Assessment of Heavy Metals of Road Runoff in Ehimiri Housing Estate Umuahia, Abia State, Nigeria"

\section{RESULTS AND DISCUSSION}

The chapter presents the summary result of environmental risk assessment of heavy metals of road runoff in Ehimiri housing estate, Umuahia. Trace Metals in Ehimiri area has pattern of iron is unimodal and is skewed towards low frequency of high concentration with a mean and standard deviation of $73.60 \pm 8.50 \mathrm{mg} / \mathrm{l}$. The highest concentration of iron was observed at ERSP7 whereas the lowest concentration was observed at ERSP3 .These value exceeded the WHO allowable limit of $1.0 \mathrm{mg} / \mathrm{l} \mathrm{WHO} \mathrm{(2006).} \mathrm{The} \mathrm{high} \mathrm{level} \mathrm{of} \mathrm{iron} \mathrm{in} \mathrm{the} \mathrm{leachate} \mathrm{samples} \mathrm{indicates} \mathrm{that} \mathrm{apart} \mathrm{from}$ background concentration, iron and steel scraps are also dumped in nearby dumpsite. The dark brown colour of the leachate is mainly attributed to oxidation of ferrous to ferric hydroxide colloids and complexes with fulvic/humic substances (Chu et al, 1994). Other metals found in runoff from outdoor storage include chromium and lead from road salt piles and arsenic from scrap metal. The list of other sources of metals is long, ranging from combustion to deteriorating metal and paint. Airborne emissions from burning substance, oil or municipal waste may carry cadmium, copper, lead or mercury(Ubuoh,2014)

Table3.1. Results of Heavy Metals from Road Run off of Ehimiri Housing Estate

\begin{tabular}{|l|l|l|l|l|l|l|l|l|l|}
\hline $\begin{array}{l}\text { Parameter } \\
(\mathrm{mg} / \mathrm{l})\end{array}$ & $\begin{array}{l}\text { ERSP1 } \\
(\mathrm{mg} / \mathrm{l})\end{array}$ & $\begin{array}{l}\text { ERSP2 } \\
(\mathrm{mg} / \mathrm{l})\end{array}$ & $\begin{array}{l}\text { ERSP3 } \\
(\mathrm{mg} / \mathrm{l})\end{array}$ & $\begin{array}{l}\text { ERSP4 } \\
(\mathrm{mg} / \mathrm{l})\end{array}$ & $\begin{array}{l}\text { ERSP5 } \\
(\mathrm{mg} / \mathrm{l})\end{array}$ & $\begin{array}{l}\text { ERSP6 } \\
(\mathrm{mg} / \mathrm{l})\end{array}$ & $\begin{array}{l}\text { ERSP7 } \\
(\mathrm{mg} / \mathrm{l})\end{array}$ & $\begin{array}{l}\text { WHO } \\
(2006)\end{array}$ & $\begin{array}{l}\text { NESREA } \\
(2009)\end{array}$ \\
\hline Zinc & 50.00 & 48.01 & 37.00 & 38.00 & 30.01 & 32.00 & 25.00 & 5.0 & 5.0 \\
\hline Lead & 20.00 & 23.00 & 22.02 & 20.00 & 26.01 & 29.01 & 29.01 & 0.05 & 1.64 \\
\hline Copper & 17.00 & 17.01 & 15.00 & 19.00 & 10.00 & 20.00 & 19.01 & 1.0 & 1.00 \\
\hline Cadmium & 0.01 & 0.01 & 0.01 & 0.01 & 0.02 & 0.02 & 0.01 & 0.01 & 0.03 \\
\hline Chromium & 3.01 & 4.01 & 2.00 & 2.00 & 1.00 & 3.01 & 1.01 & 0.05 & 1.0 \\
\hline Iron & 3.9 & 4.0 & 3.4 & 4.0 & 4.3 & 3.51 & 4.1 & 1.0 & $\mathrm{NS}$ \\
\hline Nickel & 0.506 & 0.591 & 0.52 & 0.50 & 0.504 & 0.502 & 0.505 & $<1.0$ & 70 \\
\hline
\end{tabular}

ERSPP: Ehimiri Road Runoff Sample Points; NS:Not stated

\section{Environmental Risk Assessment of Road Runoff Water Quality on the Environment}

Environmental risk assessment is commonly done by comparing measured environmental concentrations with water quality criteria set to protect the aquatic life for a long period of time (European Commission, 2003).In fact, the necessity in assessing the effects of such high concentrations events have been discussed by several authors. Reinert and Giddings (1992); Brent and Herricks (1999), and Diamond and Klaine (2006). Indeed, the contaminants reach surface waters directly through surface runoff during rain events can occur at maximum concentrations just after reaching the water body (Chèvre and Vallotton 2007), that affects aquatic organisms. Accordingly Armour (1991), Elliott (2000), Ubuoh, et al (2010d), all noted that aquatic species should be protected during rainy storm-water for environmental sustainability.

The result of this study is of concern given that the road runoff emptied into Olokoro and at OhobeAfara,Umuahia which are important sources of domestic water supply to the local communities. This conforms to the study by Maltby et al (1995), Perdikaki and Mason, (1999) when they reported the impact caused by run off water on downstream. Moreover the communities claim the stream as their source of water supply for drinking and other domestic uses. The volume and quality of such water very much fluctuate with the seasons.

Besides its effects on aquatic ecosystems, it also poses danger to people who sourced water from them.

It is pertinent to note that the trend in the concentration of heavy metals in road runoff in the study area declined with the passage of time mainly due to increased rainfall intensity. Concerning high concentrations of Cadmium and lead in rain-water, it was above the 0.05( $\left.\mu \mathrm{g} / \mathrm{l}^{-}\right)$WHO and FMENV Standard, (2006). Several studies have reported the impacts of Cadmium on the environment. The deleterious impacts include: reduced growth and development, cancer, organ damage in males (sterility), nervous system damage of man drinking such water (Riba, et al, 1997; Asuquo et al, 2004; Yilmaz, 2005; Ademoroti, 1996b; Ubuoh et al, 2012). Cadmium has been found to be toxic to fish and other aquatic organisms, which conforms with similar reports of WHO (1991), DWAF (1996). Lead $0.01(\mathrm{mg} / \mathrm{l})$ below $0.05 \mu \mathrm{g} / 1-1$ causes central and peripheral nervous system damage, kidney 
Lazarus O.Ikwa et al. "Environmental Risk Assessment of Heavy Metals of Road Runoff in Ehimiri Housing Estate Umuahia, Abia State, Nigeria"

effects, highly toxic to infants and pregnant women. (WHO, 2006). Gastrointestinal absorption of lead affects the hematopoietic system and result in reticulocytosis; severe and permanent brain damage or death, convulsion, and ataxia (WHO, 1991; Bernard, 2003).

Zinc in road runoff samples was found to be above the 5.0 ( $\mu \mathrm{g} / \mathrm{l}-1)$ WHO and FMENV Standard, (2006) for ecosystem survival. According to ATSDR(1994), Lenntech (2006) too much zinc in water can still cause eminent health problems, such as stomach cramps, skin irritations, vomiting, nausea and anaemia, and very high of it can damage the pancrease and disturb the protein metabolism, and cause arteriosclerosi . High concentrations of zinc in water can lead to a flu - like condition known as metal fever. High concentrations of it could be a danger to unborn and newborn children, when their mothers have absorbed large concentrations of it through water, blood or milk of their mothers (Lenntech, 2006). Zinc in high concentrations can likewise increase the acidity of stream water quality in which fishes are adversely affected (Ajah, 2005).

Copper concentrations in road runoff was found above the stipulated 1.0 $\mu \mathrm{g} / 1-1$ WHO's FMENV Standard, 2006 in all the routes, suspecting to come from demolition of structures in the area. High concentration copper in water have resulted to fever with atrophic changes in nasal mucous membrane , and chronic copper poisoning of water results in Wilson' disease, characterized by a hepatic cirrhosis, brain damage, demyelization, renal disease, and copper disposition in cornea (Lenntech, 2006).

Chromium was found in high concentration above the $0.050 \mu \mathrm{g} / 1-1 \mathrm{WHO}$ and FMENV Standard, (2006) in all the routes. This was suspected to be caused by heavy road construction in the area. The result is in agreement with the findings of Lenntech (2006) who observed that chromium is used in metal alloys and pigment for cement and at low-level exposure can irritate the skin and cause ulceration, kidney and liver damage. It often accumulates in aquatic life, adding to the danger of eating fish from polluted streams with chromium.

\section{REFERENCE}

Anderson, A., Pyatt, D., Stannard, J., (1990). The effects of clearfelling a Sitka spruce stand on the water balance of a peaty grey soil at Kershope Forest. Cumbria Forestry 63, 51- 71.application of some existing models. Catena 67, 35-49.

Armour, C(1991): Guidance for evaluating and recommending temperature regimes to protect fish. Washington DC, US department of the Interior, Fish and Wildlife Service: 13 chemical and mineralogical assessment. Human Ecol. Risk Assess.12: 1991, 374-389.

Ashauer, R., Boxall A., et al. (2006). Predicting effects on aquatic organisms from fluctuating or pulsed exposure to pesticides. Environ Toxicol Chem 25(7): 1899-1912.

Atulegwu Patrick Uzoije(2005) The impact of urban run-off on Ogbor River.Nigerian Journal of Technology, Vol. 24, No. 1,

Brent, R. and Herricks . (1999). A method for the toxicity assessment of wet weather events. Water Research 33(10): 2255-2264.

Brent, R. and Herricks A (1999). method for the toxicity assessment of wet weather events. Water Research 33(10):

Brent,R. and Herricks A( 1999) method for the toxicity assessment of wet weather events Water Research 33(10): 2255-2264.

Bryan, R.B. and Campbell, I.A., 1986. Runoff and sediment discharge in a semi-arid drainagebasin. Zeitschrift fur Geomorphologie 58, 121-143.

Bultot, F., Dupriez, G.L., Gellens, G., 1990. Simulation of land use changes and impacts on the water balance - a case study for Belgium. Journal of Hydrology 114, 327-348

Burkhardt, M., Kupper, T. et al. (2005). Biozide in Fassadenbeschichtungen. Auswaschung mitFolgen. COVISS 11: 6-9.

Burton, G. A. and Pitt, R. E. (2002). Stormwater Effects Handbook. A tool for Watershed managers, scientists and engineers. Lewis Publishers, CRC Press, Boca Raton (Fl), USA.

Carolyn D. Johnson (1997) Polluted Urban Runoff - A Source of Concern. University of Wisconsin extension 
Lazarus O.Ikwa et al. "Environmental Risk Assessment of Heavy Metals of Road Runoff in Ehimiri Housing Estate Umuahia, Abia State, Nigeria"

Chèvre, N. Vallotton, L. (2007): Rossi, Risk assessment of urban runoff pollution in rivers: how to deal with time-varying concentrations? IPTEH, Faculty of Earth Sciences and Environment, University of Lausanne, CH-1015 Lausanne, Switzerland.

Chèvre, N., Loepfe, C. (2006). Pestizide in Schweizer Oberflächengewässern. Wirkungsorientierte Qualitätskriterien. gwa 4: 297-307.

Croke, J., Nethery, M., (2006) Modelling runoff and soil erosion in logged forests: Scope and flows in the Purapel river basin of central Chile. Journal of Hydrology 327, 249-257.

Diamond, J. M., Klaine, S. J. et al. (2006). Implications of pulsed chemical exposures for aquatic life criteria and wastewater permit limits. Environ Sci Technol 40: 5132-5138.

Diamond, J.M. Klaine S.J. (2006): Implications of pulsed chemical exposures for aquatic life criteria and wastewater permit limits. Environ Sci Technol 40: 5132-5138.

Duzgoren -Aydin, N.C ,Wang, Z Aydin, A. and Li. (2006): You, Fate of Heavy Metal Contaminations in Road Dusts and Gully Sediments in Guangzhou, Southeast China: A Chemical and Mineralogical Assessment . Human Ecological Risk Assessment, 12:, 374-389.

Elliott, J. (2000). Pools as refugia for Brown Trout during two summer droughts: trout responses to thermal and oxygen stress. Journal of Fish Biology 56: 938-948.

European Commission (2003). Technical Guidance Document on Risk Assessment. TGD Part II. Institute for Health and Consumer Protection, European Commission (EC), Ispra, Italy.

Gash, J. H. C., (1979). An analytical model of rainfall interception by forests. Quart. J. R. Met.

Griggs, G.B Grimanis A.P., Grimani , M.V. (1997): Bottom sediments in a polluted marine environment, Upper Saronikos Gulf, Greece. Environ. Geol. 2(2): 97-106.

Hoffman, et al. (2000). Comparison of pesticides in eight U.S. Urban streams. Environ Toxicological Chem 19(9): 2249-2258.

Horton, R.E., 1919. Rainfall interception. Mon. Weather Rev., 47, 603-623.

Jain, M.K., Kothyari, U. C., Raju, K.G. R. 2004. A GIS based distributed rainfall-runoff model. Journal of Hydrology 299, 107-135.

Jinchi Z, Jiang J, Daoping L, Donald L. D (2009) Vegetation coverage influence on rainfall- runoff relation based on wavelet analysis Journal of American Science :5(2) 97-104

Jurgensen, T. A. and Hoagland, K. D. (1990). Effects of short-term pulses of atrazine on attached algal communities in a small stream. Archive of Environmental Contamination and Toxicology 19: 617-623.

Krejci, V., Frutiger, A. et al. (2004) Projet STORM: Impacts des rejets pluviaux urbains sur les milieux récepteurs. Eawag, Dübendorf,Switzerland.

National Land and Water Resources Audit Advisory Council (2008) Turbidity/Suspendedparticulate Matter In aquatic Environments

Nowell, L. and Resek, E.(1994). National standards and guidelines for pesticides in water, sediment, and aquatic organisms: application to water-quality assessment. Reviews of Environmental Contamination and Toxicology 140: 1-164.

Olarewaju, G.O., Sa'id, M.D. and Ayodele, J.T (2008) trace metal concentrations in leachates from open dumpsites in lokoja, kogi state, Nigeria

Pizarro, R., Araya, S. Jordan, C. et al, (2005). Theeffects of changes in vegetative cover on river

Rauch, W., Krejci, V. et al. (2002). "REBEKA-a software tool for planning urban drainage on the basis of prediced impacts on receiving waters." Urban Water 4: 355-361.

Reinert, K. H., Giddings, J. M. (2002). "Effects analysis of time-varying or repeated exposures in aquatic ecological risk assessment of agrochemicals." Environ Toxicol Chem 21(9): 1977-1992.

Reinert, K.H.. Giddings, J.M.(1992): "Effects analysis of time-varying or repeated exposures in aquaticecological risk assessment of agrochemicals." Environ Toxicol Chem 21(9): 1977-1992

Revitt, D. M., Ellis, J. B. (2002). Seasonal removal of herbicides in urban runoff. Urban Water 4: 1319.

Rossi, L. and Hari (Submitted). "Impact of urban storm water on the temperature of the receiving waters: A simple procedure to estimate its harmfulness to fish populations 
Lazarus O.Ikwa et al. "Environmental Risk Assessment of Heavy Metals of Road Runoff in Ehimiri Housing Estate Umuahia, Abia State, Nigeria"

Rossi, L., Fankhauser, R. et al. (Accepted). Water quality criteria for total suspended solids (TSS)in urban wet-weather discharges. Water Science and Technology.

Rossi, L. and Hari, R. (2004). Temperature veränderungen im Gewässer bei Regenwetter. Gwa 11:795-805.

Roussel, P. (1999). Système d'évaluation de la qualité des cours d'eau. Rapport de presentation SEQEau, Agence de l'eau Loire-Bretagne.Soc 105, 43-55

Ubuoh, E.A Okpiliya, F.I. Sam-Kamange, I.M. and Egbe, C.A. (2010d) "Influence of Industrial Effluents On Quality Of Onyide River Within the Aluminum Extrusion Industry at Ikeduru , Imo, Nigeria". International Research $J$. in Engineering, Science and Technology (IREJEST), Volume 6,Number (2)

Ubuoh,E.A. Nwawuike,N ,. Obeta3 ,M.C;. Osujiek,D.N (2014)Environmental Risk Assessment of Heavy Metal Concentrations in Road Runoff with Absorption Atomic Spectrophotometer(AAS) Imo State, Nigeria. Journal of Environment and Earth Science,ISSN 2224-3216 (Paper) ISSN 2225-0948 (Online) Vol. 4, No.5, 2014

UWEX(1997) polluted urban run off. Environmental resource center, university of Wisconsin

Vallotton, N., Eggen, R. I. et al. (2006). Effect assessment of short herbicidal exposure to algae: a comparison between herbicides with different modes of action. SETAC Europe $16^{\text {th }}$ Annual Meeting. The Hague, The Netherlands.

Vallotton, N., Eggen, R. I. et al. (Submitted). Effect of pulse herbicidal exposure on Scenedesmus vacuolatus: a comparison of two photosystem II inhibitors.

Watanabe, K., Yoshimura, C. et al. (2005). Stochastic model for recovery prediction of macro invertebrates following a pulse-disturbance in River. Ecological Modelling 189(3/4):396-412.

Zabel, T. and Cole, S. M. (1999). The derivation of environmental quality standards for the protection of aquatic life in the UK. Journal of Water and Environmental Management 13:

Zhang, Jiang Jiang, Daoping Liu, Donald L. DeAngelis (2003 )Vegetation coverage influence on rainfall-runoff relation based on wavelet analysis Jinchi College of Forest Resource and Environment, Nanjing Forestry University Nanjing, China, 